\title{
HOW LEARNING DISABILITIES TEACHERS IN THE KINGDOM OF SAUDI ARABIA DEFINE STUDENTS WITH GIFTEDNESS AND LEARNING DISABILITIES
}

\author{
YasirAlsamiri \\ Faculty of Education, University of Hail, Saudi Arabia \\ e-mail: yasser1352@hotmail.com
}

\begin{abstract}
This study set out to examine how learning disabilities teachers define Students with Gifted and Learning Difficulties (SGLD). One rationale for interviewing learning disabilities teachers is that they work with students with learning disabilities and may be more aware than others of some of the characteristics of SGLD. The other rationale is that the education system in the Kingdom of Saudi Arabia does not focus on giftedness very much, and therefore, only a small number of teachers of giftedness were available for this study. The qualitative data garnered from the interviews were analysed using content analysis. Nine learning disabilities teachers participated in this study. Findings from the study suggested that the learning disabilities teachers' definitions of SGLD are limited, indicating a lack of understanding of the characteristics of SGLD. The results of this study may assist teachers and educational personnel in seeking the optimal methods to identify and assist SGLD.
\end{abstract}

Keywords: giftedness and learning disabilities, learning disabilities teachers

\section{BAGAIMANA GURU DARI SISWA DENGAN KESULITAN BELAJAR DI ARAB SAUDI MENDEFINISIKAN SISWA BERBAKAT DAN KESULITAN BELAJAR}

\begin{abstract}
Abstrak: Penelitian ini bertujuan untuk menggali bagaimana guru siswa berbakat dan kesulitan belajar (SGLD) mendefinisikan arti berbakat serta kesulitan belajar yang dialami oleh siswa mereka. Salah satu alasan utamanya adalah karena karena mereka merupakan orang yang seharusnya sangat dekat dengan siswa-siswa tersebut, sehingga mereka selayaknya lebih paham serta mengetahui karakteristik dari siswa berbakat tersebut. Alasan lainnya adalah karena sistem pendidikan di Arab Saudi belum banyak memberikan perhatian pada pendidikan bagi anak berbakat serta mengalami kesulitan belajar, yang salah satunya tercermin dari sedikitnya jumlah guru anak berbakat ini. Data kualitatif yang diperoleh dari interview dianalisis dengan analisis konten. Sembilan orang guru terlibat dalam penelitian ini. Hasil penelitian menunjukkan bahwa definisi guru SGLD sangatlah terbatas atau kurang, yang ditunjukkan dari kurangnya pengertian mereka tentang pengertian SGLD itu sendiri. Hasil penelitian ini dapat digunakan untuk membantu guru serta pihak terkait dalam menyediakan metode terbaik untuk mengidentifikasi serta membantu siswa berbakat serta kesulitan belajar.
\end{abstract}

Kata kunci: kebutuhan khusus dan kesulitan belajar, guru anak dengan kesulitan belajar

\section{INTRODUCTION}

In 1975, the Education for All Handicapped Children Act recognized the rights of all handicapped students, but it was not until 2004 with the reauthorization of the Individuals with Disabilities Education Act (IDEA) that the twiceexceptional student was actually mentioned (IDEA, 2004; Leggett, Shea, \& Wilson, 2010). However, Students with Giftedness and Learning Disability (SGLD) are usually not identified as requiring additional support, and if they are, the focus is usually on remediation, on addressing their learning disability rather than their giftedness (Maddocks, 2018; Wormald, 2011). In Saudi Arabia, SGLD is not yet widely acknowledged or understood (Alsamiri, 2018).

Teachers everywhere seem to have great difficulties in defining GSLD, so they are not often able to satisfy these students' educational needs in the setting of the mainstream classroom (Lovett \& Sparks, 2011; Pepanyan, Fisher, \& Wallican-Green, 2018). It is argued that teachers tend to focus mainly on the specific learning difficulties, so they rarely estimate and nominate high abilities (Alsamiri, 2018; Brody \& Mills, 1997; Lo \& Yuen, 2014; Maddocks, 2018). This 
is despite the fact that, according to Bracamonte (2010), between $2 \%$ and $5 \%$ of learning disabled students are gifted, and between $2 \%$ and $5 \%$ of gifted students are learning disabled. In the United States, just over 39\% of 300 school psychologists surveyed indicated moderate to considerable familiarity with SGLD, while just over $60 \%$ reported having little to no familiarity at all (Francis et al., 2010).

Internationally, and in particular in KSA, there is no clearly defined process for reporting the number of SGLD either (Alsamiri, 2018; Pepanyan et al., 2018). Thus, it is difficult to know just how many SGLD there are. For instance, studies in the United States suggest that there may be more than 300,000 students who are twice-exceptional who are not receiving appropriate support or programmes (FoleyNicpon, Allmon, Sieck, \& Stinson, 2011; Wood \& Estrada-Hernandez, 2009; Zhbanova \& Rule, 2018). However, because there are no standard methods to identify twice-exceptionality in the United States, it is difficult to know how many such students there are. This problem is compounded by a lack of accountability requirements at the federal level. A similar situation exists in Australia, where SGLD are not readily recognised (Wormald \& Clark, 2018; Wormald, Vialle, \& Rogers, 2014).

There is no clear-cut definition of SGLD because the characteristics that define such students are so broad (Foley-Nicpon et al., 2011; Ronksley-Pavia, 2015). For many years, the term twice-exceptional or gifted learning disabled has been considered something of a paradox. How could a student have a learning disability while simultaneously have giftedness? Much of the research defines SGLD as learners who are gifted in one or more areas but have a learning disability that causes them difficulty in other areas (Alsamiri, 2018; Foley-Nicpon et al.). However, it seems incomprehensible to some educators that a learner can have both giftedness and learning disabilities, and this then poses difficulties in terms not only of identifying such students, but also of providing appropriate intervention strategies to support them (Berman, Schultz, \& Weber, 2012; Brody \& Mills, 1997; Crepeau-Hobson \& Bianco, 2011; Willard-Holt, Weber, Morrison, \& Horgan, 2013).

The National Twice Exceptional Community of Practice in the United States
(Baldwin, Omdal, \& Pereles, 2015) has provided a basic framework for assisting twice exceptional students, including specialised methods of identification, appropriate educational opportunities and support, accommodations and interventions, and of particular importance is the necessity for appropriately trained academic professionals and ongoing professional development in twice exceptionality. While this framework, which is the most comprehensive to date, is useful, it also demonstrates why it can be difficult to identify SGLD and to provide the necessary support for these students. The fact that SGLD's giftedness and disability can each mask the other or both can be masked together makes it extremely challenging to identify and support SGLD (Alamer, 2017; Baldwin, Baum et al., 2015). According to Baldwin et al. (2015), while an agreed upon definition of SGLD is important, it is also necessary for this definition to be accepted by teachers as well as researchers. The problems that remain once SGLD is defined are concerned with identification, that is, recognising and understanding the many and varied characteristics of such students (Alamer, 2017; Bianco \& Leech, 2010; Foley-Nicpon, 2013; Krochak \& Ryan, 2007; Pereles, Omdal, \& Baldwin, 2009).

For instance, one study demonstrates that while teachers may not be familiar with the concept of SGLD, many do recognise its existence but have difficulties recognising these students at school (Al-Hroub, 2011). An obstacle cited is large classrooms, which make individual needs more difficult to identify. According to the research (Trail, 2011), the characteristics of these students fall into four categories: academic, cognitive, interpersonal, and intrapersonal. The characteristics are common character traits that are apparent in most SGLD. Students will exhibit traits from both sides strengths and weaknesses.

Learning disability in its simplest form involves difficulty learning numeracy or literacy skills. This is usually associated with problems in information processing (Wormald, 2009). Some students with learning disabilities experience problems learning to read. They may have dyslexia and experience spatial and visual processing difficulties (Berninger \& Abbott, 2013; Wormald, Rogers, \& Vialle, 2015), such as problems perceiving numbers and letters (Besnoy, 2006; Trail, 2011). They 
may also exhibit short or long-term memory problems (Berninger \& Abbott, 2013; Gari et al., 2015), difficulty forming letters and spacing (dysgraphia) or difficulty with mathematical concepts (dyscalculia) (Dare \& Nowicki, 2015; Vaughn, Wanzek, Murray, \& Roberts, 2012). Storing and processing visual and auditory information is also problematic for such students (Gari et al., 2015; Wormald, 2009; Wong, 2013). These difficulties inhibit SGLD achievement (Bull, Espy, \& Wiebe, 2008; Geary, 2011). This is because many academic assessments, such as standardised testing, require memorisation of facts in a given timeframe. Activities with time restrictions do not always enable SGLD to do as well as other students. They also have difficulty learning things by heart, their handwriting on written assessments is often incomprehensible and poor reading performance may prevent them from understanding what is required (Gari et al., 2015).

The gifted learner has been characterised as having high ability, usually in a specific academic domain such as literacy or numeracy (Chamberlin, Buchanan, \& Vercimak, 2007; Carter, 2013; Wormald, 2009). Other features of giftedness, aside from skill in a particular domain, include strong powers of observation, a well-developed vocabulary, wide reading, ability to quickly absorb information, good recall of information, intellectual curiosity, concern about justice and injustice, unusual imagination and interest in existential questions, such as the nature of the universe and human suffering, as well as environmental issues. It is crucial, however, for these students to be supported in order for their giftedness to blossom (Berninger \& Abbott, 2013; Foley-Nicpon, 2013; Mayes, Harris, \& Hines, 2016).

Research also indicates that the characteristics of SGLD are not straightforward. SGLD have a variety of strengths and weaknesses based on the areas of their gifts and disabilities (Gari, Mylonas, \& Portešová, 2015; Song \& Porath, 2011). These characteristics are a unique combination of both giftedness and learning disabilities (Barnard-Brak, Johnsen, Pond Hannig, \& Wei, 2015). Some common strengths of SGLD are creative thinking and abstract reasoning. They tend to be imaginative and good problem solvers. SGLD can also be strong visual learners, have a large vocabulary and good mathematical reasoning, and are often spatial learners (Jarwan \& Al-Abbadi, 2014). Weaknesses can range from being emotional and easily frustrated, short-term memory problems, and poor computation skills to issues with communication skills, such as listening, written tasks, decoding, handwriting, and spelling (Alsamiri, 2018; Song \& Porath).

Paradoxically, the school system's processes often identify SGLD as having LD but regularly overlook their giftedness (Yssel, Adams, Clarke, \& Jones, 2014). Interventional approaches therefore tend to focus on students' LD-related issues to the detriment of any distinctive gifts students may have (Ruban, 2005). Johnsen and Kendrick (2005) observed that gifted students (SG) are disadvantaged if opportunities to reach their full potential are absent (Purwanta , E; Hermanto, H., Harahap , F. 2016; Wellisch \& Brown, 2012). According to Dai and Chen (2013), teachers and administrators tend to place SG in a generic category.

Based on the gaps identified in this section, this study set out to investigate: 1) How familiar are learning disability teachers with the term Students with Giftedness and Learning Disabilities or twice-exceptionality?; 2) Is there a particular method to identify SGLD?; and 3) What do learning disability teachers need to know about SGLD?

\section{METHOD \\ Research Design}

In the current research, the authors employed a qualitative research design in order to gain an in-depth understanding of LD teachers' understanding of the term Students with Giftedness and Learning Disabilities. The author developed one semi-structured interview procedure for teachers, based on a critical review of literature focused on defining SGLD through their working experience.

\section{Procedure}

The Ministry of Education granted the authors approval to conduct this study. The author contacted 12 teachers, and a total of 9 agreed to be interviewed. The teachers were contacted to organise a time to meet for the interviews, and teachers agreed to meet at their schools at a time convenient for them. Signed consent was obtained from teachers who agreed 
to participate. The interviews were conducted face to face, and all the interviews were recorded with an MP3 recorder with only the teacher and the author present in the interview room.

\section{Participants}

The average age of participating learning disability teachers was 27 years, ranging from 23 to 35 . The participating teachers had an average of eight years of teaching experience. The majority held a bachelor's degree (eight), followed by a postgraduate diploma (one). None had received any training or professional development in SGLD.

\section{Data Analysis}

An inductive content analysis (Elo \& Kyngäs, 2008) was undertaken in this study and involved several steps. Inductive content analysis relies on a coding unit consisting of words, sentences, or paragraphs that contain elements 'related to each other through their content and context' (Graneheim \& Lundman, 2004, p. 10). The first author listened to all audio-recorded interviews, reviewed the interviews, transcribed them in Arabic to confirm the accuracy of the transcripts, and corrected a few inconsistencies. Following the data analysis, the interviews were translated into English.

To ensure validity, the author forwarded two interview transcripts for independent data coding to the co-coder. The author independently coded one interview, and the co-coder coded the same interview transcript. The author and the cocoder compared the results of their coding and discussed any differences. Once an agreement was reached, the author conducted an open coding of the remaining interviews, reading them line by line and identifying initial codes.

The author then checked the results of the open coding for accuracy, carefully reading the results. The author then read the open coding several times, and as many headings as necessary were written in the margins to describe all aspects of the content (Burnard, 1996; Graneheim \& Lundman, 2004; Hsieh \& Shannon, 2005). The author then refined and clustered the emerging codes and categories into themes (Hodgetts, Nicholas, \& Zwaigenbaum, 2013). The evidence of an established theme was arrived at by triangulation of codes, frequency of occurrences, and interview quotes
(Hodgetts et al.). The author reviewed all themes for reliability; these were then reassessed and confirmed by the co-coder and author (Patel \& Rose, 2014). The involvement of author and cocoder in each stage of the data analysis enabled triangulation and peer checking (Patel \& Rose).

\section{Results}

The results of the interviews about the definition of SGLD were divided into two themes. The first theme was the characteristics relating to strengths and weaknesses of SGLD, and the second theme was the difficulty of defining SGLD.

\section{Theme 1: Characteristics Relating to Strengths and Weaknesses of SGLD}

The strengths and weaknesses that were cited by teachers as characteristics of SGLD were usually in academic areas such as mathematics, reading, and writing. For instance, the majority of the teachers claimed that SGLD can be characterised by a disparity between performance and ability, with inconsistency in performance across a number of subjects. For instance, verbal ability may be strong and mathematical performance poor (or vice versa). A recurring theme in the teachers' responses was of SGLD demonstrating learning disability or difficulties in one area and exceptional performance in another. For example:

"I am a learning disability teacher. SGLD can be defined as a student who is gifted in one or more areas but has difficulty in other areas. For example, a student who may be very good at math but whose performance in reading and writing is very poor (T 2).

Characteristics of SGLD can help teachers to understand the term of SGLD. So if the students are performing very well in mathematics, they may struggle considerably with reading. They may have difficulties with reading but have very good math abilities and high creativity ( $T$ 4).

I am aware of SGLD characteristics such as low performance levels in one subject (e.g., difficulty with writing and reading) but very high abilities in mathematics. It is possible to define SGLD from these types of characteristics"'(T 7). 
Several teachers cited exceptional performance coupled with poor memory as a characteristic strength and weakness to define SGLD. For example:

"If students perform exceptionally in math and reading but possess poor memory, this may indicate to the teacher that the student has a learning disability and giftedness " (T 1).

"Characteristics such as abstract thinking and poor memory can make SGLD very easy to identify " (T 8).

Most of the teachers participating cited creativity as a characteristic of giftedness by which to define SGLD and linked this with a learning disability in the strengths and weaknesses characteristics.

"A student was experiencing problems with reading but was very creative and highly skilled in painting. SGLD are gifted in painting and drawing, but they can often have some problems with reading and writing" (T 5).

"Characteristics that define SGLD include difficulties with reading and writing, but these students often have good memories and are very creative" (T 3).

\section{Theme 2: Difficulty in Defining SGLD}

Difficulty in defining SGLD was cited by teachers as a difficulty in identifying its characteristics. A likely reason teachers found SGLD difficult to define is that their area of specialisation is learning disabilities, and therefore, they are not overly familiar with giftedness and even less familiar with characteristics of SGLD. For example, teachers noted that:

"I am a learning disability teacher. My experience is only with learning disability students. It is difficult to define SGLD. There are no appropriate programmes or support for these students either" (T 9).

"It is not very easy to define SGLD or twice-exceptional students in primary school. This is because there are only services for learning disabilities available. There are no services for gifted learners or twice-exceptional learners" (T 6).
A factor contributing to learning disability teachers finding it difficult to define characteristics of SGLD is that the only students referred to them by classroom teachers are those who are believed to have a learning disability. None of the learning disability teachers has ever been advised that the student may have giftedness or be twice-exceptional. Because of this, classroom teachers focus on deficits, and the learning disability is the only characteristic addressed by the learning disability teacher. For example,

"A student was referred to me because the classroom teacher believed he had a learning disability with reading and writing. However, when I spoke with his mathematics teacher, he was surprised. He said, "How is that possible that he has a learning disability when he excels in mathematics?"(T 1).

"One of my students is a good public speaker at school, popular and active in school activities. However, he was referred to me because he was experiencing difficulties with writing. It is difficult to define the characteristics of these students because they are so different" (T 7).

\section{DISCUSSION}

The purpose of this study was to investigate how learning disabilities teachers in KSA primary schools define SGLD. As demonstrated in the results, teachers define the characteristics of SGLD in terms of strengths in one area and weaknesses in another. The results also indicate that a large number of teachers find SGLD difficult to define.

SGLD are clearly present in primary schools across KSA, but learning disability teachers are not aware of these students, cannot readily define who they are, and therefore, cannot meet their complex requirements. Among the respondents, most reported to be able to define SGLD according to the more obvious characteristics in areas of academic study such as reading, writing, and mathematics. Others also cited creativity as a characteristic of giftedness, while others claimed that the term SGLD was too difficult to define. These findings correspond with the literature, which shows that a clear-cut definition of SGLD is difficult because these students' characteristics are very broad (Foley- 
Nicpon et al., 2011; Maddocks, 2018; RonksleyPavia, 2015).

The characteristics cited by teachers to define SGLD are rather limited. For instance, a few teachers cited creativity as a characteristic, but very few cited abstract reasoning as a characteristic. Teachers' narrow definition of SGLD is evident in the literature also (Alsamiri, 2018; Brody \& Mills, 1997; Gari et al., 2015). The focus on learning disabilities is also mirrored in the literature, with teachers usually overlooking giftedness and referring students who demonstrate weakness in one area to learning disabilities teachers (Brody \& Mills, 1997; Song \& Porath, 2011; Wormald \& Clark, 2018).

An important aspect of these findings is that many teachers claimed that there are few to no resources at their schools to address giftedness and none at all for SGLD. This suggests that the KSA education system is based on the deficit model, whereby the disability is addressed but rarely the giftedness. In the case of SGLD, as indicated by the responses in this study, it becomes even more complex because of the wide variety of gifts and learning disabilities that SGLD present.

Overall, KSA teachers are no less likely to be able to define SGLD than their colleagues internationally. Moreover, if they were able to define the characteristics of SGLD, there would be no programmes to address these students' giftedness, much less the complex needs of SGLD. The lack of appropriate programmes and support for SGLD mirrors that in the literature, which indicates similar lack of support and programmes for these students internationally (Foley-Nicpon et al., 2011; Wood \& EstradaHernandez, 2009).

\section{STRENGTHS AND LIMITATIONS}

This study has a number of strengths. The first is that its qualitative nature provided teachers with the opportunity to discuss a category of student with which they were not overly familiar. This yields an important finding for the Saudi education system, which needs to acknowledge this category of student. The second strength is that this is the first such study undertaken in KSA.

One limitation of the study is that the interviews were conducted in only one city in KSA, Almaddenh. The second limitation is that all the teachers interviewed were male. This is due to KSA's cultural policies, which prohibit males from interviewing females. However, this lays the groundwork for possible future studies in which female teachers' definitions of SGLD may be compared with those in this study. The third limitation is that while a qualitative approach facilitates insights of the participants, a quantitative approach would allow for broader generalisation of findings.

\section{CONCLUSION}

In the field of learning disabilities in KSA, the needs of SGLD continue to be underserved. This can be attributed to a generally limited understanding of the characteristics of SGLD and to an education model that provides very few resources or programmes for giftedness. This study demonstrates the necessity of ongoing research in this area and professional development opportunities for learning disability teachers to become familiar with the concept of SGLD. Only when they are aware of the variety of ways in which a student can present as SGLD will learning disability teachers be able to address their needs more fully. There is therefore, an urgent need for the Ministry of Education in KSA first to acknowledge this category of student and then to provide the appropriate resources for SGLD and more resources for giftedness. This is important because otherwise, many students will fail to reach their true potential.

\section{ACKNOWLEDGEMENTS}

The author would like to thank the teachers involved in this study for their time and help with this study. I also thank my mother Bakhita from the bottom of my heart for her unconditional support throughout my life and for being there for me always. I also thank my wife Ajayb, whose name means wonders, for her endless support and for being my strength in all my endeavours. I would also like to thank my children, Mohammed, Ahmad and Qamar,

\section{REFERENCES}

Alamer, H. A. (2017). Exploring the experiences and insights of a twice-exceptional student finishing a college teacher preparation program: A case study (Unpublished doctoral dissertation). University of Northern Colorado. 
Al-Hroub, A. (2011). Developing assessment profiles for mathematically gifted children with learning difficulties at three schools in Cambridgeshire, England. Journal for the Education of the Gifted, 34(1), 744. doi: $10.1177 / 016235321003400102$

Alsamiri, Y. A. (2018). Teachers' perspectives of identifying students of Saudi primary students with giftedness and learning disabilities.Doctoral thesis, School of Education, University of New South Wales, Sydney, Australia.

Baldwin, L., Omdal, S. N., \& Pereles, D. (2015). Beyond stereotypes understanding, recognizing, and working with twiceexceptional learners. TEACHING Exceptional Children, 47(4), 216-225.

Barnard-Brak, L., Johnsen, S. K., Pond Hannig, A., \& Wei, T. (2015). The incidence of potentially gifted students within a special education population. Roeper Review, 37(2), 74 83. doi:10.1080/02783 193.2015.1008661

Berman, K. M., Schultz, R. A., \& Weber, C. L. (2012). A lack of awareness and emphasis in preservice teacher training: Preconceived beliefs about the gifted and talented. Gifted Child Today, 35(1), 1826. doi: 10.1177/1076217511428307

Berninger, V. W., \& Abbott, R. D. (2013). Differences between children with dyslexia who are and are not gifted in verbal reasoning. Gifted Child Quarterly, 57(4), 223-233. doi: $10.1177 / 0016986213500342$

Besnoy, K. D. (2006). Successful strategies for twice-exceptional children. Waco, TX: Prufrock Press.

Bianco, M., \& Leech, N., (2010). Twiceexceptional learners: Effects of teacher preparation and disability labels on gifted referrals. Teacher Education Division of the Council for Exceptional Children, 33(4), 319-334. doi:10.1177/0888406409356392
Bracamonte, M., (2010). 2e students: Who they are and what they need. Retrieved from http://www.thelangschool.org/News/2e Newsletter_Issue 39.pdf

Brody, L. E., \& Mills, C. J. (1997). Gifted children with learning disabilities: A review of the issues. Journal of Learning Disabilities, 30(3), 282296. doi: $10.1177 / 002221949703000304$

Bull, R., Espy, K. A., \& Wiebe, S. A. (2008). Short-term memory, working memory, and executive functioning in preschoolers: Longitudinal predictors of mathematical achievement at age 7 years. Developmental neuropsychology, 33(3), 205-228.

Burnard, P. (1996). Teaching the analysis of textual data: An experiential approach. Nurse Education Today, 16(8), 278-281. doi: 10.1016/S0260-6917(96)80115-8

Carter, S. (2013). From disability to learning gap. How some schools have accomplished it. In: Biennial Joint Conference for Learning Difficulties (LDA 2013) (pp. 1-1). Brisbane, Australia.

Chamberlin, S. A., Buchanan, M., \& Vercimak, D. (2007). Serving twice-exceptional preschoolers: Blending gifted education and early childhood special education practices in assessment and program planning. Journal for the Education of the Gifted, 30(3), 372 394. doi: $10.1177 / 016235320703000305$

Crepeau Hobson, F., \& Bianco, M. (2011). Identification of gifted students with learning disabilities in a Response to Intervention era. Psychology in the Schools, 48(2), 102 109. doi: 10.1002/ pits. 20528

Dai, D. Y., \& Chen, F. (2013). Three paradigms of gifted education in search of conceptual clarity in research and practice. Gifted Child Quarterly, 57(3), 151 168. doi: $10.1177 / 0016986213490020$ 
Dare, L., \& Nowicki, E. A. (2015). Twiceexceptionality: Parents' perspectives on 2e identification. Roeper Review, 37(4), 208-218.

Elo, S., \& Kyngäs, H. (2008). The qualitative content analysis process. Journal of Advanced Nursing, 62, 107-115. doi: 10.1111/j.1365-2648.2007. 04569.x

Foley-Nicpon, M., Allmon, A., Sieck, B., \& Stinson, R. D. (2011). Empirical investigation of twice-exceptionality: Where have we been and where are we going? GiftedChild Quarterly, 55(1), 3 17. doi: $10.1177 / 0016986210382575$

Francis, J. J., Johnston, M., Robertson, C., Glidewell, L., Entwistle, V., Eccles, M. P., \& Grimshaw, J. M. (2010). What is an adequate sample size? Operationalising data saturation for theory-based interview studies. Psychology and Health, 25(10), 1229 1245. doi: $10.1080 / 08870440903194015$

Gari, A., Mylonas, K., \& Portešová, S. (2015). An analysis of attitudes towards the gifted students with learning difficulties using two samples of Greek and Czech primary school teachers. Gifted Education International, 31(3), 271-286.doi: $10.1177 / 0261429413511887$

Geary, D. C. (2011). Consequences, characteristics, and causes of mathematical learning disabilities and persistent low achievement in mathematics. Journal of Developmental and Behavioral Pediatrics: JDBP, 32(3), 250-263.

Graneheim, U. H., \& Lundman, B. (2004). Qualitative content analysis in nursing research: Concepts, procedures and measures to achieve trustworthiness. Nurse Education Today, 24, 105-112. doi: 10.1016/j.nedt.2003.10.001

Hodgetts, S., Nicholas, D., \& Zwaigenbaum, L. (2013). Home sweet home? Families' experiences with aggression in children with autism spectrum disorders. Focus on Autism and Other Developmental Disabilities, 28, 166-174. doi: $10.1177 / 1088357612472932$

Hsieh H.- F., \& Shannon, S. (2005). Three approaches to qualitative content analysis. Qualitative Health Research, 15, $1277-$ 1288.doi: 10.1177/1049732305276687

Jarwan, F., \& Al-Abbadi, Z. (2014). The effect of an instruction program based on the creative problem solving model on developing creative thinking skills of gifted students with learning disabilities. Association of Arab Universities Journal for Education and Psychology, 12(1), 11 43.

Johnsen, S. K., \& Kendrick, J. (2005). Teaching gifted students with disabilities. Prufrock Press Inc

Krochak, L.A. \& Ryan, T.G. (2007). The challenge of identifying gifted/learning disabled students. International Journal of Special Education, 22(3), 4453.

Leggett, D. G., Shea, I., \& Wilson, J. A. (2010). Advocating for twice-exceptional students: An ethical obligation. Research in the Schools, 17(2), 1-10.

Lo, C. C., \& Yuen, M. (2014). Coping strategies and perceived sources of support among gifted students with specific learning disabilities: Three exploratory case studies in Hong Kong. Gifted and Talented International, 29(1-2), 125-136.

Lovett, B. J., \& Sparks, R. L. (2011). The identification and performance of gifted students with learning disability diagnoses: A quantitative synthesis. Journal of Learning Disabilities, 46(4), 304 316. doi: $10.1177 / 0022219411421810$

Maddocks, D. L. (2018). The identification of students who are gifted and have a learning disability: A comparison of different diagnostic criteria. Gifted Child Quarterly, 62(2), 175192. 
Mayes, R. D., Harris, P. C., \& Hines, E. M. (2016). Meeting the academic and socioemotional needs of twice exceptional African American students through group counseling. In J. Lawson Davis \& J. L. Moore (Eds.), Gifted children of color around the world: Diverse needs, exemplary practices, and directions for the future (Advances in race and ethnicity in education, Vol. 3, pp. 53-69). Emerald Group Publishing.

Patel, M., \& Rose, J. (2014). Students' attitudes towards individuals with an intellectual disability. Journal of Intellectual Disabilities, 28(4), 90-103. doi: $10.1177 / 1744629513511355$

Pepanyan, M., Fisher, M., \& Wallican-Green, A. (2018). Faces on Mars lesson: Incorporating art, thinking skills, and disability differentiation strategies for twice-exceptional gifted students. Journal of STEM Arts, Crafts, and Constructions, 3(1), 93-102.

Pereles, D., Omdal, S., \& Baldwin, L. (2009). Response to intervention and twice exceptional learners: A promising fit. Gifted Child Today, 32(3), 4051.

Purwanta , E; Hermanto, H., Harahap , F. 2016. Analisis kebutuhan untuk berwirausaha pada siswa berkebutuhan khusus. CakrawalaPendidikanNo 3 (2016).doi: http://dx.doi.org/10.21831/ cp.v35i3.11444

Ronksley-Pavia, M. (2015). A model of twice-exceptionality: Explaining and defining the apparent paradoxical combination of disability and giftedness in childhood. Journal for the Education of the Gifted. Retrieved from http:// jeg.sagepub.com/content/early/2015/0 6/29/0162353215592499 abstract doi: $10.1177 / 0162353215592499$

Ruban,L.M.(2005).Identificationandassessment of gifted students with learning disabilities. Theory Into Practice, 44(2), 115 124. doi: 10.1207/s15430421tip4402_6
Scott, M. T., Mayes, R. D., Griffith, K. G., Garrett, M. T., \& Watkins, J. (2015). Effective involvement with urban special education services: What every school counselor should know to support Black male students. In M. Henfield \& A. Washington (Eds.), Black mal e student success in 21st century urban schools: School counseling for equity, access, and achievement (pp. 173-194). Charlotte, NC: Information Age Publishing

Song, K., \& Porath, M. (2011). How giftedness coexists with learning disabilities: Understandinggiftedstudents withlearning disabilities (GLD) in an integrated model of human abilities. Talent Development and Excellence, 3(2), 215-227.

Trail, B. A. (2011). Twice-exceptional gifted children: Understanding, teaching, and counseling gifted students. Waco, TX: Prufrock Press.

Vaughn, S., Wanzek, J., Murray, C. S., \& Roberts, G. (2012). Intensive interventions for tudents struggling in reading and mathematics:Apracticeguide.Portsmouth, NH: RMC Research Corporation, Center on Instruction.

Wellisch, M., \& Brown, J. (2012). An integrated identification and intervention model for intellectually gifted children. Journal of Advanced Academics, 23(2), 145 167. doi: $10.1177 / 1932202 X 12438877$

Willard-Holt, C., Weber, J., Morrison, K. L., \& Horgan, J. (2013). Twiceexceptional learners' perspectives on effective learning strategies. Gifted Child Quarterly, 57(4), 247262. doi: 10.1177/0016986213501076

Wong, M. (2013). Finding the lost treasure: A literature review of defining and identifying gifted and talented children in early childhood settings in Aotearoa New Zealand. Te Iti Kahurangi: School of Education E-Journal, 1, 93-101. 
Wood, S. (2012). Examining parent and teacher perceptions of using the Conners 3 (An exploratory study). Roeper Review, 34, 194-204.

Wormald, C. (2009). An enigma: Barriers to the identification of gifted students with a learning disability (Unpublished doctoral thesis). School of Education, University of Wollongong, New South Wales, Australia.

Wormald, C. (2011). Teachers' knowledge of gifted learning disabled children in NSW. In C. Wormald, \& W. Vialle (Eds.), Dual Exceptionality (pp. 87 94). Wollongong: Australian Association for the Education of the Gifted and Talented.

Wormald, C., \& Clark, T. (2018). Gifted students with disability: Twice-exceptional learners. In J. L. Jolly, \& J. M. Jarvis (Eds.), Exploring Gifted Education (pp. 60-75). New York: Routledge.
Wormald, C., Vialle, W., \& Rogers, K. (2014). Young and misunderstood in the education system: A case study of giftedness and specific learning disabilities. Australasian Journal of Gifted Education, 23(2), 1628.

Yssel, N., Adams, C., Clarke, L. S., \& Jones, R. (2014). Applying an RTI model for students with learning disabilities who are gifted. Teaching Exceptional Children, $46(3), 4252$.

Zhbanova, K. S., \& Rule, A. C. (2018). Editorial: Spotlight on Edward de Bono: Thinking skills and twice-exceptional gifted learners applied to Mars mysteries in NASA photographs. Journal of STEM Arts, Crafts, and Constructions, 3(1), $1-11$. 